\title{
PERAN POLA ASUH AUTORITATIF DAN KECERDASAN EMOSIONAL TERHADAP PROBLEM FOCUSED COPING PADA REMAJA AKHIR DI PROGRAM STUDI PENDIDIKAN DOKTER FK UNUD Made Ayu Praditya Larashati, I Made Rustika \\ Program Studi Psikologi, Fakultas Kedokteran, Universitas Udayana larashatiayu@rocketmail.com
}

\begin{abstract}
Abstrak
Problem focused coping adalah usaha yang digunakan individu untuk mengurangi stres yang dihadapi dalam mengatasi masalah secara langsung dengan mengelola masalah tersebut. Taraf problem focused coping dipengaruhi oleh pengalaman-pengalaman usia dini seperti pola pengasuhan orang tua. Di samping itu kemampuan berpikir jernih dan bersikap tenang membantu individu untuk mengendalikan diri dalam menghadapi masalah. Penelitian ini bertujuan untuk melihat peran pola asuh autoritatif dan kecerdasan emosional terhadap problem focused coping pada remaja akhir. Subjek penelitian ini adalah 156 remaja akhir di Program Studi Pendidikan Dokter Fakultas Kedokteran Universitas Udayana. Instrumen penelitian ini adalah skala problem focused coping, skala kecerdasan emosional, dan skala pola asuh autoritatif. Hasil yang diperoleh dari analisis regresi ganda menunjukkan nilai $\mathrm{R}=0,510$ ( $\mathrm{p}<0,05)$ dan nilai koefisien determinasi sebesar 0,260, dengan demikian dapat disebutkan bahwa pola asuh autoritatif dan kecerdasan emosional secara bersama-sama berperan sebesar $26 \%$ terhadap problem focused coping pada remaja akhir. Koefisien beta terstandarisasi kecerdasan emosional sebesar 0,484 dan signifikansi 0,000 $(\mathrm{p}<0,05)$ menunjukkan kecerdasan emosional berperan terhadap problem focused coping. Koefisien beta terstandarisasi pola asuh autoritatif sebesar 0,084 dan signifikansi 0,240 (p>0,05) menunjukkan pola asuh autoritatif tidak berperan terhadap problem focused coping.
\end{abstract}

Kata Kunci: problem focused coping, kecerdasan emosional, pola asuh autoritatif, remaja akhir

\begin{abstract}
Problem focused coping is the effort that an individual uses to reduce stress in addressing the problem directly by managing its fundamental problem. Problem focused coping can be developed through early childhood experiences including the involvement of parenting style. The ability of individuals to settle down and think clearly also play roles in controlling their problem solving capability. This study aimed to explore the role of authoritative parenting style and emotional intelligence to the problem focused coping in late adolescent. The subjects were 156 late adolescents in Department of Medicine, Udayana University. The instrument in the research were problem focused coping, emotional intelligence, and authoritative parenting scale. The results of multiple regression analysis showed the value of $\mathrm{R}=0.510(\mathrm{p}<0.05)$ and $\mathrm{R} 2=0,260$, which concluded that the authoritative parenting style and emotional intelligence conjunctly contributes as much as $26 \%$ to problem focused coping in late adolescents. Standardized beta coefficient of authoritative parenting style showed the value of 0.084 ( $p>0.05$ ), which concluded that an authoritative parenting style doesn't contribute to the problem focused coping. Standardized beta coefficient emotional intelligence showed the value of $0.484(\mathrm{p}<0.05)$, which concluded that emotional intelligence contributes to the problem focused coping.
\end{abstract}

Keywords: problem focused coping, emotional intelligence, authoritative parenting, late adolescents 


\section{LATAR BELAKANG}

Coping adalah usaha untuk mengelola situasi yang membebani atau menimbulkan stres dan memperluas usaha mengelola situasi tersebut untuk mengatasi masalah atau stres dalam kehidupan (Santrock, 2007b). Seiffge-Krenke, Aunola dan Nurmi (2009), menjelaskan bahwa stres memiliki peran penting dalam perkembangan masa remaja. Kemampuan coping penting dikembangkan untuk membantu remaja dalam mengatasi atau mengurangi stres yang terjadi dalam masa remaja (Santrock, 2007b).

Masa remaja adalah suatu periode peralihan dari masa anak-anak ke masa dewasa. Periode peralihan merupakan periode penting karena segala sesuatu yang terjadi mempengaruhi sikap dan perilaku remaja serta menimbulkan dampak jangka panjang (Hurlock, 1980). Masa remaja juga disebut sebagai periode pencarian identitas yang menyebabkan remaja menjadi sosok dewasa yang mengembangkan pemahaman diri sendiri yang baik dan memiliki peran di masyarakat (Hurlock, 1980; Papalia, Olds, \& Feldman, 2009).

Perubahan kognitif, biologis dan sosio-emosional juga terjadi pada masa remaja. Perubahan kognitif ditandai dengan adanya peningkatan pola berpikir abstrak, idealislitik dan logis, sehingga menyebabkan pemikiran remaja menjadi lebih egosentris yang mana menimbulkan pandangan mengenai dirinya sebagai sosok yang unik dan tidak terkalahkan. Perubahan biologis pada masa remaja disebut sebagai periode pubertas, sehingga terjadi pertambahan tinggi tubuh, perubahan hormonal dan kematangan seksual (Santrock, 2007a). Perubahan sosio-emosional mengarah pada perubahan sikap dan perilaku yang menimbulkan nilai-nilai baru dalam membina hubungan sosial (Hurlock, 1980).

Perubahan biologis yang mempengaruhi perubahan fisik dan diikuti dengan perubahan psikologis menyebabkan terjadinya perubahan emosi. Perubahan emosi selama masa remaja menimbulkan ketidakstabilan dalam emosi. Emosi remaja diekspresikan dengan cara yang beragam seperti bersuara keras, menggerutu atau berdiam diri. Perubahan emosi terjadi lebih cepat selama masa awal remaja, namun emosi yang meninggi cenderung menonjol pada masa remaja akhir (Hurlock, 1980).

Menurut Ali dan Asrori (2012), remaja akhir cenderung sudah memiliki emosi yang stabil. Kestabilan emosi ditunjukkan remaja akhir dengan mampu mencapai kematangan emosional yang menyebabkan remaja menunjukkan perilaku tidak melibatkan atau mengekspresikan emosi secara liar dalam mengatasi masalah, namun menujukan perilaku menunggu situasi yang tepat untuk mengekspresikan emosi sesuai dengan nilai-nilai dewasa di masyarakat (Hurlcok, 1980). Pencapaian kematangan emosional terjadi pada masa remaja akhir karena masa remaja akhir merupakan proses penyatuan menuju masa kedewasaan sehingga remaja mampu memisahkan sesuatu yang bersifat pribadi dengan sesuatu yang bersifat umum (Sarwono, 2013). Remaja akhir yang tidak mampu mencapai kematangan emosional menyebabkan remaja sulit mengatasi masalah sehingga dapat memicu stres (Ali \& Asrori, 2012).

Remaja akhir yang merupakan mahasiswa fakultas kedokteran memiliki kecenderungan mengalami stres lebih tinggi dibandingkan dengan mahasiswa dari fakultas lain karena materi dan sistem perkuliahan yang padat serta waktu yang diperlukan untuk menyelesaikan perkuliahan sekitar 5 tahun (Navas, 2012). Surve dkk (2015) mengemukakan bahwa faktor akademik memiliki pengaruh terhadap stres yang dihadapi mahasiswa kedokteran. Maulana, Soleha, Saftarina dan Siagian (2014) juga mengemukakan bahwa mahasiswa kedokteran memiliki kecenderungan mengalami stres ringan hingga berat karena jadwal perkuliahan dan praktikum yang padat. Tinggi dan rendahnya tingkat stres mahasiswa kedokteran dapat mempengaruhi perilaku dan proses belajar mahasiswa (Abdulghani, Alkanhal, Mahmoud, Ponnamperuma \& Alfaris, 2011). Maka, mengembangkan kemampuan coping sangat penting dalam mengatasi stres (Susanto, 2013).

Menurut Lazarus (1993) coping merupakan sebuah proses, dimana mengelompokkan pikiran dan tindakan yang dinilai merugikan atau menguntungkan dalam mengelola kebutuhan. Coping mempengaruhi reaksi stres dengan 2 cara yaitu problem focused coping dan emotional focused coping (Lazarus, 1993). Menurut Heppner \& Lee (dalam Santrock, 2007b), problem-focused coping cenderung bekerja lebih baik dalam jangka waktu panjang dibandingkan dengan emotionalfocused coping. Problem focused coping berfokus dalam memecahkan masalah untuk menghadapi kondisi yang menimbulkan stres sehingga mengubah hubungan individu dengan lingkungan sekitarnya. Problem focused coping tidak melibatkan emosi dalam mengatasi masalah tertentu (Carver, Scheier \& Weintraub, 1989; Lazarus, 1993).

Hasil penelitian Sari (2010) menunjukkan bahwa remaja akhir cenderung menggunakan problem focused coping dalam mengatasi masalah. Ketika tidak mampu mengembangkan problem focused coping menyebabkan individu tidak mampu mengatasi masalah yang dihadapi namun menambah berat beban masalah. Perilaku individu yang dapat menambah beban masalah yaitu menggunakan obat-obat terlarang, melarikan diri dengan minum minuman keras, perilaku seks bebas, dan kegiatan negatif lain (Safaria, 2006). Perilaku-perilaku yang menambah beban masalah masih ditemukan dikalangan remaja akhir seperti yang dilaporkan oleh Badan Narkotika Nasional bahwa 22 persen dari 480.000 pelajar dan mahasiswa di DKI Jakarta merupakan pengguna narkotik (Suryanis, 2014). Fadillah (2013) mengemukakan bahwa remaja akhir yang berusia 20 tahun mengadakan pesta narkoba di rumahnya bersama 17 orang 
lainnya dan polisi menyatakan 13 orang dinyatakan positif mengonsumsi narkoba. Selain terlibat dalam penggunaan obatobat terlarang, sekelompok remaja dari usia 13 sampai 19 tahun terlibat dalam kelompok geng motor dan melakukan pesta miras (Tribun Batam, 2015).

Dari pemaparan yang telah disampaikan, timbul pertanyaan mengapa ada remaja akhir yang mampu mengembangkan problem focused coping dan ada remaja akhir yang tidak mampu mengembangkan problem focused coping?

Pola asuh orangtua di dalam sebuah keluarga memiliki peran penting dalam perkembangan coping remaja (Wolfaardt, Hempel, \& Miles, 2003; Susanto, 2013). Pola asuh orangtua merupakan perilaku yang nampak ketika orangtua melakukan komunikasi dan membangun hubungan emosional pada remaja (Wolfaardt dkk, 2003). Terdapat empat tipe pola asuh orang tua yaitu autoritarian, autoritatif, permisif dan tidak terlibat (Baumrind, 1971).

Menurut Wolfaardt dkk (2003), pola asuh orangtua yang bersifat hangat dan khusus memiliki hubungan terhadap strategi coping remaja karena kehangatan yang ditunjukkan ayah berhubungan dengan kehangatan yang ditunjukkan ibu, begitupula dengan tekanan dan kontrol yang ditunjukkan ayah berhubungan dengan tekanan dan kontrol yang ditunjukan ibu sehingga mempengaruhi kemampuan adaptasi anak. Pola asuh orangtua yang menerapkan kehangatan adalah pola asuh autoritatif (Darling \& Steinberg, 1993). Orangtua dengan pola asuh autoritatif memiliki keseimbangan dalam menuntut dan memberikan respon. Metode pendisiplinan pada orangtua dengan pola asuh autoritatif lebih mendukung dibandingkan dengan metode pemberian hukuman (Baumrind, 1991).

Orangtua dengan pola asuh autoritatif mengarahkan kegiatan remaja secara rasional dan berorientasi pada isu-isu permasalahan. Orangtua berfokus pada kualitas remaja dan menentukan standar perilaku menggunakan alasan, kekuatan dan kekuasaan tanpa langsung memenuhi keinginan remaja. Dalam pembuatan kebijakan orangtua menggunakan komunikasi dua arah dengan remaja sehingga remaja dapat menyampaikan pendapatnya dan orangtua dapat mendengarkan pendapat tersebut, begitu pula sebaliknya. Pendapat yang disampaikan remaja berupa kebijakankebijakan yang dirasa remaja memberatkan dirinya sehingga diperlukan beberapa perbaikan agar remaja dapat menyesuaikan kebijakan tersebut (Baumrind, 1966).

Standar perilaku dan kebijakan yang telah dibentuk, serta komunikasi dua arah yang digunakan oleh orangtua dengan pola asuh autoritatif membantu remaja dalam meningkatkan kemampuan pemecahan masalah (problem solving) (Suparmi \& Ngahu, 2006). Kemampuan pemecahan masalah yang meningkat menyebabkan remaja mampu mengembangkan problem-focused coping, karena pengembangan problem focused coping memerlukan kemampuan pemecahan masalah (Folkman, Lazarus, DunkelSchetter, DeLongis \& Gruen, 1986).

Selain pola asuh autoritatif, hasil penelitian yang dilakukan Saptoto (2010) menjelaskan bahwa kecerdasan emosional memiliki peran dalam pengembangan problem focused coping pada remaja. Menurut Salovey (dalam Goleman, 2015), kecerdasan emosional adalah kemampuan individu dalam memahami emosi yang dirasakan, mengelola emosi, adanya motivasi diri, berempati kepada orang lain, dan membina hubungan dengan orang lain.

Kemampuan mengenali emosi secara objektif menyebabkan individu tidak melibatkan emosi dalam mengatasi masalah dan mampu menyelesaikan masalah yang sedang dihadapi secara langsung (Saptoto, 2010). Menghadapi masalah secara langsung merupakan salah satu kemampuan confrontive coping dalam problem focused coping (Folkman dkk, 1986). Individu yang mampu mengenali emosi dapat mengelola emosi dalam mengatasi masalah. Mengelola emosi menyebabkan individu tidak mengungkapkan emosi secara liar atau menekan emosi secara mendalam karena individu mampu menghibur diri dan melepaskan kecemasan sebagai salah satu cara untuk menyeimbangkan emosi positif dan negatif. Melepaskan kecemasan dan mampu menghibur diri merupakan perwujudan dari kemampuan motivasi diri karena individu tidak pesimis, pantang menyerah dan berusaha untuk mengatasi masalah dan tetap berfokus untuk mencapai tujuan (Saptoto, 2010). Pantang menyerah, tidak pesimis dan berusaha merupakan usaha individu menciptakan makna positif dengan berfokus pada pengembangan diri. Individu yang mampu menciptakan makna positif memiliki kemampuan positive reappraisal dalam problem focused coping (Folkman dkk, 1986).

Kemampuan berempati menyebabkan individu mampu memahami perasaan dan menerima pendapat dari sudut pandang orang lain sehingga inividu berhati-hati dalam mengambil keputusan dan tidak cepat menyalahkan orang lain ketika sedang mengatasi masalah (Saptoto, 2010). Pengambilan keputusan menyebabkan individu mengembangkan rasa tanggung jawab sehingga berkembang kemampuan menerima tanggung jawab (accepting responsibility) dalam problem focused coping (Folkman dkk, 1986).

Kehati-hatian dalam mengambil keputusan menyebabkan individu melakukan diskusi dengan orang lain untuk mencari solusi bersama-sama dalam mengatasi suatu masalah sehingga berkembang kemampuan membina hubungan (Saptoto, 2010). Mencari solusi bersama-sama dapat mengembangkan kemampuan perencanaan pemecahan masalah (planful problem solving), karena individu berfokus pada masalah dan bersikap tenang dalam mengatasi masalah yang terjadi (Folkman dkk, 1986). 
Remaja yang mampu memahami emosi, mengelola emosi, memotivasi diri, berempati dan mampu membina hubungan dengan orang lain adalah remaja yang memiliki kecerdasan emosional yang tinggi. Remaja yang memiliki kecerdasan emosional yang tinggi juga memiliki kemampuan problem focused coping yang tinggi (Saptoto, 2010).

Berdasarkan pemaparan yang telah dijelaskan, maka peneliti ingin mengetahui apakah terdapat peran pola asuh autoritatif dan kecerdasan emosional terhadap problem focused coping pada remaja akhir di Program Studi Pendidikan Dokter FK UNUD serta mengetahui apakah terdapat peran pola asuh autoritatif terhadap problem focused coping pada remaja akhir di Program Studi Pendidikan Dokter FK UNUD dan apakah terdapat peran kecerdasan emosional terhadap problem focused coping pada remaja akhir di Program Studi Pendidikan Dokter FK UNUD. Penelitian ini diharapkan dapat menambahkan informasi teoritis dalam bidang Ilmu Psikologi Perkembangan dan Psikologi Klinis. Manfaat praktis dalam penelitian ini adalah untuk membantu remaja akhir mengatasi permasalahan atau kondisi stres dengan membaca hasil penelitian sehingga mereka memahami bagaimana cara-cara efektif dalam melakukan menghadapi permasalahan, membantu keluarga untuk mengembangkan kemampuan menghadapi permasalahan yang berfokus pada masalah dengan membaca hasil penelitian ini sehingga memahami cara-cara efektif dalam menghadapi permasalahan dengan menerapkan pola asuh autoritatif dan mengembangan kecerdasan emosional anak, membantu pihak universitas dan organisasi mahasiswa dalam menciptakan rancangan program untuk mengembangkan kecerdasan emosional mahasiswa yang dapat membantu mahasiswa melakukan dan mengembangkan cara-cara efektif dalam menghadapi permasalahan, dan membantu peneliti selanjutnya dalam mendapatkan informasi dalam mengembangkan problem focused coping atau pemecahan masalah pada remaja akhir berdasarkan peran orangtua yang menerapkan pola asuh autoritatif dan kecerdasan emosional.

\section{METODE}

\section{Variabel dan definisi operasional}

Variabel bebas dalam penelitian ini adalah pola asuh autoritatif dan kecerdasan emosional serta variabel tergantung dalam penelitian ini adalah problem focused coping. Definisi operasional dari masing-masing variabel dalam penelitian ini sebagai berikut:

\section{Problem Focused Coping}

Problem focused coping adalah usaha yang dilakukan individu untuk mengatasi masalah dengan melakukan confrontive coping, accepting responsibility, planful problem solving, dan positive reappraisal. Pengukuruan dilakukan dengan menggunakan skala Problem Focused Coping (PFC), semakin tinggi skor total maka semakin tinggi taraf problem focused coping yang dilakukan.

\section{Pola Asuh Autoritatif}

Pola asuh autoritatif adalah pola pengasuhan orangtua dengan pemberian kontrol dan afeksi secara seimbang yang mengutamakan kualitas anak dengan melibatkan anak secara aktif dalam menetapkan standar melalui komunikasi dua arah dan membimbing anak untuk memiliki sikap tegas, bertanggungjawab, mandiri serta kooperatif. Pengukuran dilakukan dengan menggunakan skala Pola Asuh Autoritatif (PAA), semakin tinggi skor total maka semakin tinggi taraf penerapan pola asuh autoritatif orangtua terhadap anak.

3. Kecerdasan Emosional

Kecerdasan emosional adalah kemampuan individu dalam mengenali gejolak emosi, mengatur emosi, memotivasi diri, berempati dan membina hubungan dengan orang lain. Pengukuran dilakukan dengan menggunakan skala Kecerdasan Emosional (KE), semakin tinggi skor kecerdasan emosional maka semakin tinggi taraf kecerdasan emosional.

\section{Responden}

Populasi penelitian menggunakan remaja akhir yang menempuh studi di Program Studi Pendidikan Dokter Fakultas Kedokteran Universitas Udayana. Karaktersitik subjek dalam penelitian ini sebagai berikut:

1. Remaja yang berusia 18 hingga 21 tahun.

2. Remaja yang menempuh pendidikan di Program Studi Pendidikan Dokter Fakultas Kedokteran Universitas Udayana.

Teknik pengambilan sampel dalam penelitian ini adalah simple random sampling. Simple random sampling adalah teknik pengambilan anggota sampel secara acak tanpa memperhatikan strata dalam populasi (Sugiyono, 2012). Proses random yang peneliti lakukan menggunakan daftar hadir mahasiswa, sehingga dari proses tersebut menghasilkan 369 skala yang terkumpul dari empat angkatan PSPD dan peneliti mendapatkan 325 skala yang terisi dengan lengkap. Pada proses uji asumsi, peneliti membuang 169 outlier yang menyebabkan data tidak normal sehingga jumlah subjek yang memenuhi karakteristik dan dapat dianalisis adalah 156 orang.

\section{Tempat penelitian}

Penelitian dilakukan di Program Studi Pendidikan Dokter (PSPD) Fakultas Kedokteran UNUD pada bulan Oktober 2015, yaitu pada tanggal 21 Oktober 2015 di PSPD angkatan 2014, 22 Oktober 2015 di PSPD angkatan 2012, 26 Oktober 2015 di PSPD angkatan 2013, dan 27 Oktober 2015 di PSPD angkatan 2015. 


\section{Alat ukur}

Alat ukur penelitian ini menggunakan tiga skala yaitu, skala problem focused coping, skala pola asuh autoritatif dan skala kecerdasan emosional. Skala problem focused coping disusun oleh peneliti sendiri menggunakan teori Folkman dan Lazarus (1986), skala pola asuh autoritatif menggunakan skala yang disusun oleh Rustika (2014) dan skala kecerdasan emosional dimodifikasi dari skala Rustika (2014). Skala problem focused coping terdiri dari 18 item pernyataan, skala pola asuh autoritatif terdiri dari 23 item pernyataan dan skala kecerdasan emosional terdiri dari 29 item pernyataan. Pernyataan pada skala penelitian ini tediri dari kalimat positif (favorable) dan kalimat negatif (unfavorable) yang diberikan skor 1 sampai 4. Pada skala problem focused coping, pola asuh autoritatif dan kecerdasan emosional terdapat 4 respon terhadap pernyataan, yaitu Sangat Tidak Sesuai (STS), Tidak Sesuai (TS), Sesuai (S) dan Sangat Sesuai (SS).

Hasil uji validitas skala problem focused coping menunjukkan nilai koefisien korelasi item total berkisar antara 0,253 sampai 0,526. Hasil uji reliabilitas skala problem focused coping pada saat uji coba menunjukkan koefisien Alpha $(\alpha)$ sebesar 0,799 yang memiliki arti bahwa skala problem focused coping mampu mencerminkan 79,9\% variasi skor murni subyek, sehingga dapat disimpulkan bahwa skala problem focused coping layak digunakan sebagai alat ukur untuk mengukur atribut yang dimaksudkan, yaitu problem focused coping.

Hasil uji validitas skala kecerdasan emosional menunjukkan nilai koefisien korelasi item total berkisar antara 0,25 sampai 0,698. Hasil uji reliabilitas skala problem focused coping pada saat uji coba menunjukkan koefisien Alpha $(\alpha)$ sebesar 0,906 yang mememiliki arti bahwa skala kecerdasan emosional mampu mencerminkan $90,6 \%$ variasi skor murni subyek, sehingga dapat disimpulkan bahwa skala kecerdasan emosional layak digunakan sebagai alat ukur untuk mengukur atribut yang dimaksudkan, yaitu kecerdasan emosional.

\section{Teknik analisis data}

Hal pertama yang dilakukan sebelum analisis data untuk uji hipotesis adalah melakukan uji asumsi data penelitian yaitu uji normalitas, uji linearitas, dan uji multikolinearitas. Pada penelitian ini uji normalitas dilakukan menggunakan Kolmogorov Smirnov, uji linearitas dilakukan menggunakan Compare Means dan uji multikolinearitas dilakukan dengan melihat nilai variance inflation factor (VIF) dan tolerance. Setelah melakukan uji asumsi, data penelitian dapat di analisis menggunakan metode analisis regresi berganda untuk menguji hipotesis mayor dan hipotesis minor. Metode analisis regresi berganda digunakan untuk mengetahui peran dari dua atau lebih variabel bebas terhadap satu variabel tergantung (Santoso, 2003). Analisis data dilakukan dengan menggunakan bentuan perangkat lunak SPSS versi 17.0.

\section{HASIL PENELITIAN}

\section{Karakteristik Subjek}

Berdasarkan hasil data karakteristik subjek, penelitian ini memiliki 159 subjek yang terdiri dari 59 lakilaki dan 97 perempuan dengan rentang usia 18 sampai 21 tahun. Mayoritas subjek yang mengikuti penelitian ini berusia 19 tahun dengan persentase sebesar 37,2\%. Orangtua subjek memiliki pendidikan terakhir yang beragam yaitu SD, SMP, SMA, diploma, S1, S2 dan S3 namun mayoritas orangtua subjek berpendidikan S1 dengan persentase $45,5 \%$ pada ayah dan $39,1 \%$ pada ibu.

\section{Deskripsi Data Penelitian}

Hasil deskripsi data penelitian yaitu problem focused coping, kecerdasan emosional dan pola asuh autoritatif dapat dilihat pada tabel 1 .

Tabel 1

\begin{tabular}{|cccccccc} 
Deskripsi Statistik Data Penelitian & \multicolumn{1}{l}{$l$} & \\
\hline Variabel & $\mathbf{N}$ & $\begin{array}{c}\text { Mean } \\
\text { Teoritis }\end{array}$ & $\begin{array}{c}\text { Mean } \\
\text { Empiris }\end{array}$ & $\begin{array}{c}\text { Std } \\
\text { Deviasi } \\
\text { Teoritis }\end{array}$ & $\begin{array}{c}\text { Std } \\
\text { Deviasi } \\
\text { Empiris }\end{array}$ & $\begin{array}{c}\text { Sebaran } \\
\text { Teoritis }\end{array}$ & $\begin{array}{c}\text { Sebaran } \\
\text { Empiris }\end{array}$ \\
\hline PFC & 156 & 45 & 52,19 & 9 & 3,079 & $18-72$ & $45-60$ \\
\hline KE & 156 & 72,5 & 83,00 & 14,5 & 4,704 & $29-116$ & $72-94$ \\
\hline PAA & 156 & 57,5 & 68,84 & 11,5 & 3,623 & $23-92$ & $61-75$ \\
\hline
\end{tabular}

Berdasarkan tabel 1, variabel problem focused coping memiliki mean empiris yang lebih besar dari mean teoritis sehingga menghasilkan perbedaan sebesar 7,19. Mean empiris yang didapat lebih besar dari mean teoritis (mean empiris > mean teoritis) menghasilkan sebuah kesimpulan bahwa subjek memiliki taraf problem focused coping yang tinggi. Berdasarkan penyebaran frekuensi menghasilkan rentang skor subjek penelitian berkisar antara 45 sampai 60 terdapat $98,7 \%$ subjek memiliki skor diatas mean teoritis.

Berdasarkan tabel 1, variabel pola asuh autoritatif memiliki mean empiris yang lebih besar dari mean teoritis sehingga menghasilkan perbedaan sebesar 11,34. Mean empiris yang didapat lebih besar dari mean teoritis (mean empiris > mean teoritis) menghasilkan sebuah kesimpulan bahwa subjek diasuh dengan pola asuh autoritatif yang tinggi. Berdasarkan penyebaran frekuensi menghasilkan rentang skor subjek penelitian berkisar antara 61 sampai 75 terdapat $100 \%$ subjek memiliki skor diatas mean teoritis.

Berdasarkan tabel 1, variabel kecerdasan emosional memiliki mean empiris yang lebih besar dari mean teoritis sehingga menghasilkan perbedaan sebesar 10,5. Mean empiris yang didapat lebih besar dari mean teoritis (mean empiris > mean teoritis) menghasilkan sebuah kesimpulan bahwa subjek memiliki kecerdasan emosional yang tinggi. Berdasarkan penyebaran frekuensi menghasilkan rentang skor subjek penelitian berkisar antara 72 sampai 94 terdapat $98,1 \%$ subjek memiliki skor diatas mean teoritis. 


\section{Uji Asumsi}

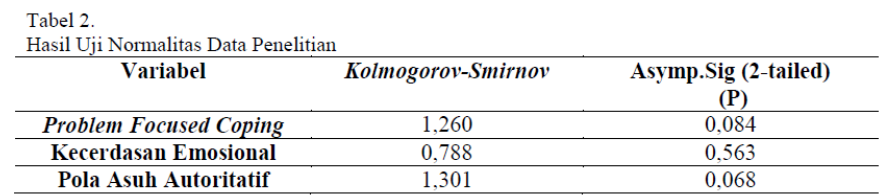

Uji normalitas pada penelitian ini menggunakan Kolmogorov Smirnov dengan bantuan SPSS version 17.0. Menurut Santoso (2005) menjelaskan bahwa data penelitian dapat dikatakan normal apabila nilai $p>0,05$. Pada saat melakukan uji normalitas dengan jumlah subjek sebanyak 325 orang, hasil uji normalitas pada penelitian ini menunjukkan data penelitian ini tidak berdistribusi normal sehingga peneliti melakukan penghapusan outlier. Outlier adalah pengamatan yang memiliki jarak ekstrem dari nilai-nilai dalam sampel suatu populasi. Penghapusan outlier dilakukan apabila memberikan pengaruh terhadap proses uji selanjutnya dan menganggu normalitas data secara keseluruhan. Sejauh ini tidak ada batas maksimal dari penghapusan outlier pada data suatu penelitian (Suryani \& Hendryadi, 2015). Penghapusan outlier dilakukan sedikit demi sedikit sehingga peneliti mendapatkan hasil uji normalitas yang menunjukkan data penelitian ini berdistribusi normal dengan jumlah subjek sebanyak 156 orang. Berdasarkan tabel 2, diketahui bahwa data pada variabel problem focused coping dapat dikatakan telah berdistribusi normal karena memiliki nilai KolmogorovSmirnov sebesar 1,260 dengan signifikansi 0,084 ( $p>0,05)$. Data pada variabel pola asuh autoritatif dapat dikatakan telah berdistribusi normal karena memiliki nilai KolmogorovSmirnov sebesar 1,301 dengan signifikansi 0,068 ( $p>0,05)$. Data pada variabel kecerdasan emosional dapat dikatakan telah berdistribusi normal karena memiliki nilai KolmogorovSmirnov sebesar 0,788 dengan signifikansi 0,563 ( $p>0,05)$.

\begin{tabular}{lcccc} 
Tabel 3. \\
Hasil Uji Linearitas Data Penelitian & & & \\
\hline & & & F & Sig. \\
\hline $\begin{array}{c}\text { Problem Focused } \\
\text { Coping*Kecerdasan } \\
\text { Emosional }\end{array}$ & $\begin{array}{c}\text { Between } \\
\text { Groups }\end{array}$ & Linearity & 54,984 & 0,000 \\
\hline $\begin{array}{c}\text { Problem Focused } \\
\text { Coping }{ }^{*} \text { Pola Asuh } \\
\text { Autoritatif }\end{array}$ & $\begin{array}{c}\text { Between } \\
\text { Groups }\end{array}$ & Deviation from Linearity & 1,384 & 0,137 \\
\hline
\end{tabular}

Uji linearitas digunakan untuk mengetahui adanya hubungan yang linear antara variabel bebas dengan variabel tergantung. Menguji linearitas menggunakan uji compare mean dengan melihat nilai signifikansi pada Linierity dibawah $0,05(\mathrm{p}<0,05)$ dan nilai signifikansi pada Deviation from Linearity diatas 0,05 ( $>0,05)$ (Priyatno, 2012). Uji linearitas pada penelitian ini menggunakan SPSS version 17.0. Berdasarkan tabel 3, diketahui bahwa variabel problem focused coping dan kecerdasan emosional memiliki signifikansi linearity sebesar $0,000(p<0,05)$ dan signifikansi deviation from linearity sebesar $0,137(p>0,05)$. Pada variabel problem focused coping dan pola asuh autoritatif yang memiliki signifikansi liniearity sebesar 0,016 dan signifikansi deviation from linearity sebesar $0,621(p>0,05)$. Maka dapat disimpulkan bahwa terdapat hubungan linear antara problem focused coping dengan kecerdasan emosional dan problem focused coping dengan pola asuh autoritatif.

Tabel 4.

\begin{tabular}{cccc} 
Tabel 4. & & \\
Hasil Uji Multikolinearitas Data Penelitian & & Keterangan \\
\hline Variabel & Tolerance & $\begin{array}{c}\text { Variance Inflation } \\
\text { Factor (VIF) }\end{array}$ & Tidak ada multikolinearitas \\
\hline $\begin{array}{c}\text { Kecerdasan } \\
\text { Emosional }\end{array}$ & 0,949 & 1,054 & \\
\hline
\end{tabular}

\begin{tabular}{llll}
\hline Pola Asuh Autoritatif & 0,949 & 1,054 & Tidak ada multikolinearitas
\end{tabular}

Uji multikolinearitas digunakan untuk melihat korelasi antar variabel-variabel bebas. Metode regresi dianggap baik ketika variabel bebas tidak memiliki gejala multikolinearitas, hal tersebut dapat dilihat dari nilai VIF dibawah 10 dan nilai Collinierity Tolerance diatas $0,1 . \mathrm{Uji}$ multikolinearitas pada penelitian ini menggunakan SPSS version 17.0. Berdasarkan tabel 4, diketahui bahwa variabel kecerdasan emosional dan pola asuh autoritatif memiliki nilai tolerance sebesari 0,949 dan nilai VIF sebesar 1,053, sehingga dapat disimpulkan bahwa variabel bebas pada metode regresi penelitian ini dianggap baik karena tidak terjadi multikolinearitas.

Berdasarkan hasil uji asumsi yang telah dilakukan, peneliti mendapatkan hasil bahwa data penelitian ini memiliki distribusi normal, memiliki hubungan yang linear, dan tidak terjadi multikolinearitas.

\section{Uji Hipotesis}

Berikut merupakan hasil uji regresi berganda antara pola asuh autoritatif dan kecerdasan emosional terhadap problem focused coping:

Tabel 5

Hasil Uji Regresi Berganda Pola Asuh Autoritatif dan Kecerdasan Emosional terhadap Problem Focused Coping

\begin{tabular}{cccc}
\multicolumn{2}{l}{ Focused Coping } \\
\hline $\mathbf{R}$ & $\mathbf{R}$ Square & Adjusted R Square & Std. Error of the Estimate \\
\hline 0,510 & 0,260 & 0,250 & 2,666 \\
\hline
\end{tabular}

Uji regresi ganda digunakan untuk mengetahui peran dari dua variabel bebas atau lebih terhadap satu variabel tergantung (Santoso, 2003). Uji regresi berganda pada penelitian ini menggunakan SPSS version 17.0. Berdasarkan tabel 5, diketahui bahwa koefisien regresi (R) sebesar 0,510 dan koefisien determinasi ( $\mathrm{R}$ Square) sebesar 0,260 maka dapat disimpulkan bahwa pola asuh autoritatif dan kecerdasan emosional secara bersama-sama menentukan $26 \%$ taraf problem focused coping. Dengan demikian variabel lain yang tidak diteliti menentukan $74 \%$ taraf problem focused coping.

Tabel 6 .

Hasil Uji Regresi Berganda Signifikansi Nilai F

\begin{tabular}{cccccc}
\multicolumn{7}{c}{ Hasil Uji Regresi Berganda Signifikansi Nilai $F$} & & & \\
\hline Sum of Squares & Df & Mean Square & F & Sig \\
\hline Regression & 382,184 & 2 & 191,092 & 26,886 & 0,000 \\
\hline Residual & 1087,425 & 143 & 7,107 & & \\
\hline Totak & 1468,609 & 155 & & & \\
\hline
\end{tabular}

Berdasarkan tabel 6, diketahui bahwa nilai $\mathrm{F}$ hitung sebesar 26,886 dan signifikasi sebesar 0,000 ( $<<0,005)$, sehingga dengan demikian model regresi dalam penelitian ini 
dapat digunakan untuk memprediksi problem focused coping. Kesimpulan yang didapat adalah pola asuh autoritatif dan kecerdasan emosional secara bersama-sama berperan terhadap problem focused coping.

Tabel 7.

Hasil Uji Regresi Berganda Nilai Koefisien Beta dan Nilai T Variabel Kecerdasan Emosional dan

Unstandarized Asuh Autoritatif Terhadap Problem Focused Coping.
Polandarized

\begin{tabular}{|c|c|c|c|c|c|}
\hline \multirow[b]{2}{*}{ Model } & \multicolumn{2}{|c|}{$\begin{array}{l}\text { Unstandarized } \\
\text { Coefficients }\end{array}$} & \multirow{2}{*}{$\begin{array}{r}\text { Standarized } \\
\text { Coefficient }\end{array}$} & \multirow[b]{2}{*}{ T } & \multirow[b]{2}{*}{ Sig. } \\
\hline & B & Std. Error & & & \\
\hline (Constant) & 20,948 & 5,019 & & 4,173 & 0,000 \\
\hline $\begin{array}{c}\text { Kecerdasan } \\
\text { Emosional }\end{array}$ & 0,317 & 0,047 & 0,484 & 6,781 & 0,000 \\
\hline Pola Asuh & 0,072 & 0,061 & 0,084 & 1,181 & 0,240 \\
\hline
\end{tabular}

Autoritatif

Berdasarkan tabel 7, diketahui bahwa nilai koefisien beta terstandarisi kecerdasan emosional lebih besar dari nilai koefisien beta terstandarisasi pola asuh autoritatif, yang memiliki arti bahwa kecerdasan emosional memiliki peran yang lebih banyak terhadap problem focused coping dibandingkan dengan pola asuh autoritatif. Kecerdasan emosional memiliki koefisien beta yang terstandarisasi sebesar 0,484, nilai t sebesar 6,781 dan signifikansi $0,000(\mathrm{p}<0,05)$, sehingga kecerdasan emosional berperan secara signifikan terhadap problem focused coping. Pola asuh autoritatif memiliki koefisien beta yang terstandarisasi sebesar 0,084, nilai t sebesar 1,181, dan signifikansi 0,240 ( $>>0,05)$, sehingga pola asuh autoritatif tidak berperan secara signifikan terhadap problem focused coping karena nilai signifikansi lebih besar dari 0,05 .

Berdasarkan tabel 7, hasil uji regresi berganda dapat memprediksi taraf problem focused coping dari masingmasing subjek dengan melihat nilai konstan, beta terstandarisasi dan skor subjek. Memprediksi taraf problem focused coping apabila subjek memiliki kecerdasan emosional yang tinggi dapat dihitung dengan melakukan penambahan setiap satuan skor subjek pada skala kecerdasan emosional maka akan terjadi kenaikan taraf problem focused coping sebesar 0,484.

Rangkuman hasil uji hipotesis mayor dan hipotesis minor dalam penelitian ini dapat dilihat pada tabel 8 .

\section{Tabel 8 .}

\begin{tabular}{clc}
\multicolumn{1}{c}{ Hangkuman Hasil Uji Hipotesis Penelitian } & \\
\hline No & \multicolumn{1}{c}{ Hipotesis } & Diterima \\
\hline 1 & $\begin{array}{l}\text { Hipotesis Mayor : } \\
\text { Pola asuh autoritatif dan kecerdasan } \\
\text { emosional berperan terhadap problem } \\
\text { focused coping remaja akhir. }\end{array}$ & Ditolak \\
\hline 2 & $\begin{array}{l}\text { Hipotesis Minor : } \\
\text { a. Pola asuh autoritatif berperan terhadap } \\
\text { problem focused coping remaja akhir. } \\
\text { Kecerdasan emosional berperan } \\
\text { terhadap problem focused coping } \\
\text { remaja akhir. }\end{array}$ & Diterima \\
&
\end{tabular}

\section{PEMBAHASAN DAN KESIMPULAN}

Berdasarkan hasil penelitian yang telah dipaparkan, subjek penelitian ini adalah remaja akhir yang berusia 18 tahun sampai 21 tahun. Presentase subjek berusia 18 tahun sebesar $23,1 \%$; berusia 19 tahun sebesar $37,2 \%$; berusia 20 tahun sebesar 25,6\%; dan berusia 21 tahun sebesar 14,1\%. Subjek penelitian ini mayoritas perempuan, karena presentase subjek perempuan sebesar $62,2 \%$ sedangkan subjek laki-laki sebesar $37,8 \%$.

Remaja akhir di Program Studi Pendidikan Dokter FK UNUD mampu mengembangkan problem focused coping karena terdapat peran yang signifikan dari pola asuh autoritatif dan kecerdasan emosional, sehingga hipotesis mayor pada penelitian ini diterima. Peran yang signifikan dari pola asuh autoritatif dan kecerdasan emosional dapat dilihat dari koefisien regresi sebesar 0,510, nilai $\mathrm{F}$ sebesar 26,886 dengan signifikansi sebesar 0,000. Koefisien determinasi pada penelitian ini memiliki nilai sebesar 0,260 yang memiliki arti bahwa pola asuh autoritatif dan kecerdasan emosional memiliki sumbangan efektif sebesar $26 \%$ terhadap problem focused coping. Kesimpulan yang didapat adalah pola asuh autoritatif dan kecerdasan emosional secara bersama-sama menentukan $26 \%$ taraf problem focused coping pada remaja akhir, dan sisanya sebesar $74 \%$ dipengaruhi oleh variabel lain yang tidak diteliti pada penelitian ini.

Remaja akhir yang diasuh dengan pola asuh autoritatif dan memiliki kecerdasan emosional yang tinggi mempengaruhi dirinya dalam melakukan problem focused coping karena remaja akhir mampu mengekspresikan perasaan secara tepat, menyusun alternatif masalah, mampu bertanggung jawab dan memaknai peristiwa atau permasalahan sebagai proses pengembangan diri. Individu yang diasuh dengan pola asuh autoritatif mampu bersikap tegas, bertanggung jawab, mandiri dan kooperatif (Baumrind, 1991). Individu yang memiliki kecerdasan emosional tinggi mampu menghadapi permasalah dengan tenang dan produktif (Goleman, 2015).

Hasil analisis koefisien beta terstandarisasi dari kecerdasan emosional menunjukkan nilai sebesar, 0,484 dan nilai $\mathrm{t}$ sebesar 6,781 dengan signifikansi $0,000 \quad(\mathrm{p}<0,05)$ memiliki arti bahwa kecerdasan emosional berpengaruh secara signifikan terhadap problem focused coping pada remaja akhir di Program Studi Pendidikan Dokter FK. Individu yang memiliki kecerdasan emosional yang tinggi dapat mengetahui dan mengatasi perasaan diri dengan baik sehingga individu mampu mengelola dirinya. Individu yang mampu mengelola diri cenderung tidak mengekspresikan perasaan yang dirasakan secara liar serta mampu bersikap tenang. Menurut Goleman (2000) individu yang mampu bersikap tenang dan menciptakan atau mencari gagasan-gagasan baru dalam menyusun alternatif-alternatif berdasarkan berbagai pertimbangan sehingga individu memiliki keyakinan diri untuk mempu menyelesaikan permasalahan, karena kecerdaan emosional memengaruhi ketrampilan kognitif yang menyebabkan individu dapat menggunakan potensi diri dengan maksimal. 
Individu yang memiliki kecerdasan emosional tinggi dapat menghadapi masalah dan mendapatkan makna positif dari masalah yang timbul. Menurut Goleman (2015), individu mampu bekerja secara produktif dan dapat menguasai pola pikir yang dapat membuat individu berpikir jernih, melakukan introspeksi diri, dan mampu memunculkan motivasi dalam menghadapi suatu permasalahan. Hal tersebut sejalan dengan penelitian yang dilakukan Fajarwati (2005) yaitu individu yang mampu berpikir jenih, melakukan instrospeksi diri dan memunculkan motiviasi menyebabkan individu mampu memahami peran-peran yang dimiliki, mampu bertanggung jawab atas perilaku yang ditunjukkan dan keputusan yang dibuat, serta memandang bahwa permasalahan yang dihadapinya merupakan salah satu cara untuk mengembangkan diri.

Individu juga memiliki kemampuan mengenali dan menghadapi perasaan orang lain menyebabkan individu mampu membina hubungan dengan orang lain. Hal tersebut disebabkan karena individu yang sedang menghadapi suatu permasalahan membutuhkan orang lain untuk melakukan diskusi sehingga memunculkan saran atau gagasan baru. Proses dalam diskusi cenderung membuat individu tidak hanya memikirkan permasalahan yang dihadapi dari sudut pandangnya saja, tetapi mampu untuk memposisikan dirinya di sudut pandang orang lain. Individu yang mampu memahami sudut pandang orang lain menyebabkan individu dapat melakukan negosiasi untuk menyelesaikan suatu masalah (Fajarwati, 2005; Saptoto, 2010).

Hasil analisis koefisien beta yang terstandarisasi pada pola asuh autoritaitf menunjukkan nilai sebesar 0,084 , nilai $\mathrm{t}$ sebesar 1,181, dan signifikansi 0,240 memiliki arti bahwa pola asuh autoritatif tidak beperan secara signifikan terhadap problem focused coping pada remaja akhir di Program Studi Pendidikan Dokter FK UNUD. Semakin bertambahnya usia seorang anak, peran pola asuh yang diterapkan oleh orangtua tidak langsung berpengaruh terhadap perilaku anak, karena peran pola asuh orangtua sudah membentuk kepribadian yang dimiliki anak (Santrock, 2007b).

Pada masa kanak-kanak, orangtua merupakan sosok penting bagi anak sehingga peran pola asuh yang diterapkan orangtua sangat berpengaruh secara langsung terhadap perilaku anak di kehidupan sehari-hari. Peran pola asuh orangtua mempengaruhi anak untuk mampu memahami dan mengendalikan diri sendiri karena peran tersebut menyebabkan anak memiliki dorongan untuk berprestasi, mampu menyesuaian diri dengan lingkungan, mengetahui peran sosial dan peran seks yang dimiliki dalam berinteraksi, kemampuan memimpin, kemampuan mencapai tujuan serta kemampuan berkreativitas (Hurlock, 1980). Memasuki masa remaja, peran orangtua sedikit demi sedikit mulai berkurang, karena lingkungan sosial yang dihadapi remaja semakin luas dan terdapat kecenderungan bahwa remaja menghabiskan waktunya lebih banyak bersama teman sebaya dibandingkan orangtua. Pada masa remaja, terdapat berbagai macam gejolak yang mempengaruhi tingkat stres remaja. Remaja yang memiliki kepribadian yang baik cenderung mampu memahami dan mengendalikan diri sehingga dapat mengatasi gejolak dan stres yang dihadapi. (Santrock, 2007b). Kemampuan dalam memahami dan mengendalikan diri merupakan perwujudan dari kemampuan mengenali dan mengelola emosi yang dirasakan, mampu memotivasi diri ketika menghadapi situasi yang buruk, mampu berempati dengan orang lain serta membina hubungan dengan orang lain (Goleman, 2015).

Remaja akhir yang berasal dari keluarga autoritatif cenderung dapat memahami dan mengendalikan diri karena remaja menerapkan peran pola asuh yang diterapkan dalam mencari berbagai informasi atau pengetahuan sesuai dengan nilai-nilai yang dimiliki, melakukan adaptasi di lingkungan baru maupun dalam mencari teman atau pasangan hidup (Respati, Yulianto, Widiana, 2006). Orangtua yang menerapkan pola asuh autoritatif memberikan keseimbangan pada afeksi dan kontrol dalam mengasuh anak (Baumrind, 1966). Afeksi yang diberikan orangtua dapat dilihat dari cara orangtua menunjukkan repson positif terhadap perilaku yang dimunculkan anak dan penggunakan bahasa secara hati-hati dalam berkomunikasi sehingga remaja akhir terbiasa meniru perilaku serupa dan mampu mengelola emosi yang dirasakan.

Berbagai sudut pandang yang diberikan orangtua dalam berinteraksi dan melakukan pemecahan masalah dengan anak menyebabkan remaja akhir mampu memotivasi diri ketika merasa sedih dan mampu memahami perasaan atau sudut pandang orang lain. Pemberian kontrol yang diberikan orangtua dapat dilihat dari cara orangtua mengarahkan perilaku anak dengan menentukan standar perilaku secara tegas melalui komunikasi dua arah sehingga remaja akhir mampu beperilaku sesuai yang diharapkan lingkungan dalam membina hubungan dan menghargai pendapat orang lain dalam melakukan diskusi. Kemampuan mengenali dan mengelola emosi, memotivasi diri, berempati dan membina hubungan dengan orang lain merupakan kemampuankemampuan yang diperlukan dalam kecerdasan emosional.

Berdasarkan pemarapan yang telah disampaikan, dapat disimpulkan bahwa pada masa remaja akhir peran pola asuh autoritatif yang secara tidak langsung mempengaruhi problem focused coping tetapi mungkin akan mempengaruhi ke kecerdasan emosional terlebih dahulu. Hal tersebut sejalan dengan hasil penelitian yang dilakukan oleh Rustika (2014) bahwa pola asuh autoritatif memiliki peran secara langsung terhadap kecerdasan emosional remaja akhir.

Pada deskripsi statistik data penelitian menunjukkan bahwa problem focused coping memiliki mean teoritis sebesar 45 dan mean empiris 52,19. Mean empiris yang didapat lebih besar dari mean teoritis (mean empiris > mean teoritis) sehingga membuktikan bahwa remaja akhir Program Studi 
Pendidikan Dokter FK UNUD memiliki taraf problem focused coping yang tinggi. Hasil kategorisasi data problem focused coping menunjukkan subjek dengan taraf problem focused coping sedang memiliki presentase sebesar 29,5\%, taraf problem focued coping tinggi sebesar 69,2\%, dan taraf problem focused coping sangat tinggi sebesar $1,3 \%$. Tingginya taraf problem focused coping pada remaja akhir Program Studi Pendidikan Dokter FK UNUD dipengaruhi oleh kegiatan diskusi atau small group discussion (SGD) dalam sistem perkuliahan. Kegiatan SGD merupakan fasilitas yang diberikan kepada mahasiswa kedokteran untuk melakukan diskusi dalam mencari jawaban dari permasalahan yang diberikan saat lecture setiap hari. Kegiatan SGD yang dilakukan setiap hari menyebabkan mahasiswa kedokteran terbiasa untuk menghadapi suatu permasalahan dan mencari berbagai alternatif dalam memecahkan masalah. Rohmah (2006) mengemukakan bahwa proses diskusi mempengaruhi mahasiswa dalam menambah wawasan, berbagi pengalaman, membantu mahasiswa dalam memecahkan masalah dan memiliki strategi pemecahan masalah yang dapat digunakan di masa mendatang. Dalam penelitian ini pengukuran terhadap efektivitas SGD belum dilakukan sehingga belum didapat data empiris yang pasti terkait efektivitas SGD, sehingga diharapkan adanya penelitian lebih lanjut mengenai efektivitas SGD dalam mengembangkan pemecahan masalah secara langsung atau problem focused coping.

Pada deskripsi statistik data penelitian menunjukkan bahwa kecerdasan emosional memiliki mean teoritis sebesar 72,5 dan mean empiris 83. Mean empiris yang didapat lebih besar dari mean teoritis (mean empiris > mean teoritis), sehingga membuktikan bahwa remaja akhir di Program Studi Pendidikan Dokter FK UNUD memiliki kecerdasan emosional yang tinggi. Hasil kategorisasi data kecerdasan emosional menunjukkan bahwa subjek yang memiliki kecerdasan emosional sedang menunjukkan presentase sebesar 31,4\% dan kecerdasan emosional tinggi sebesar 68,6\%. Tingginya kecerdasan emosional yang dimiliki remaja akhir di Program Studi Pendidikan Dokter FK UNUD dipengaruhi oleh proses diskusi dalam kegiatan small group discussion (SGD). Proses diskusi yang terjadi dalam SGD menyebabkan mahasiswa kedokteran diajarkan untuk mampu menyampaikan pendapat yang dimiliki tanpa menjatuhkan orang lain dan mampu menghargai perbedaan pendapat yang terjadi dalam proses diskusi tersebut. Menurutu Rohmah (2006) proses diskusi menyebabkan mahasiswa dapat mengembangkan potensi diri karena mahasiswa dapat mengenal diri, mengetahui kelebihan dan kekurangan diri, percaya diri, mempunyai persepsi positif, mempunyai motivasi intrinsik dan belajar menghargai serta mempertahankan pendapat. Goleman (2015) mengemukakan bahwa individu yang mampu mengembangkan potensi diri adalah individu yang memiliki kecerdasan emosional yang tinggi karena individu mampu mengenali dan mengelola emosi diri dalam menyampaikan pendapat serta membina hubungan yang baik dengan orang lain. Dalam penelitian ini pengukuran terhadap efektivitas SGD belum dilakukan sehingga belum didapat data empiris yang pasti terkait efektivitas SGD, sehingga diharapkan adanya penelitian lebih lanjut mengenai efektivitas SGD dalam pengembangan kecerdasan emosional.

Tidak hanya proses diskusi melalui SGD, remaja akhir dalam penelitian ini memiliki kecerdasan emosional tinggi karena peran pola asuh autoritatif yang diterapkan orangtua juga tinggi, yaitu sebesar $91 \%$ berdasarkan hasil kategorisasi data penelitian. Orangtua yang menerapkan pola asuh autoritatif menyebabkan anak dapat melakukan komunikasi dua arah dalam berdiskusi dengan menggunakan interaksi yang hangat berupa penggunaan bahasa secara hatihati dan memberikan respon positif (Baumrind, 1966).

Pada deskripsi statistik data penelitian menunjukkan bahwa pola asuh autoritatif memiliki mean teoritis sebesar 57,5 dan mean empiris 68,84. Mean empiris yang didapat lebih besar dari mean teoritis (mean empiris > mean teoritis) sehingga membuktikan bahwa remaja akhir di Program Studi Pendidikan Dokter FK UNUD diasuh dengan pola asuh autoritatif yang tinggi. Hasil kategorisasi pola asuh autoritatif, menunjukkan bahwa subjek yang diasuh dengan pola asuh autoritatif sedang memiliki presentase sebesar 9\% dan diasuh dengan pola asuh autoritatif tinggi sebesar 91\%. Tingginya pola asuh autoritatif pada remaja akhir di Program Studi Pendidikan Dokter FK UNUD dipengaruhi oleh tingkat pendidikan orangtua. Mayoritas orangtua subjek berpendidikan tinggi yaitu $\mathrm{S} 1, \mathrm{~S} 2$, dan $\mathrm{S} 3$ dengan persentase ayah berpendidikan tinggi sebesar $73,1 \%$ dan ibu sebesar 53,9\%. Menurut Farida dan Naviati (2014) orangtua yang berpendidikan tinggi cenderung menerapkan pola asuh autoritatif kepada anak. Orangtua yang berpendidikan tinggi akan memberikan berbagai alternatif dan jawaban dalam melakukan diskusi sehingga membuat anak berpikir lebih matang terhadap keputusan yang akan diambil (Haryanti, 2014). Dasmo, Nurhayati dan Marhento (2012) mengemukakan bahwa orangtua yang berpendidikan tinggi berusaha untuk memberikan pendidikan terbaik untuk anak. Orangtua memberikan pendidikan terbaik karena orangtua mengutamakan kualitas anak (Baumrind, 1966). Dalam Penelitian ini uji beda terhadap data pendidikan orangtua belum dilakukan sehingga belum didapat data empiris yang pasti terkait variasi pada pola asuh berdasarkan pendidikan orangtua, sehingga diharapkan adanya penelitian lebih lanjut mengenai tingkat pendidikan orangtua terhadap pemilihan pola asuh yang diterapkan orangtua.

Keterbatasan yang dimiliki peneliti dalam penelitian ini adalah terjadinya ketidaknormalan data penelitian dengan 369 subjek sehingga menyebabkan peneliti melakukan penghapusan outlier. Penghapusan outlier dilakukan sedikit 
demi sedikit sehingga mendapatkan hasil uji normalitas bahwa data penelitian ini berdistribusi normal dengan jumlah subjek 156 orang. Peneliti memperkirakan bahwa data tidak berdistribusi normal pada awal uji normalitas dipengaruhi karena ketidakseriusan subjek dalam memberikan jawaban dari pernyataan yang terdapat di dalam kuisioner dan program studi pendidikan dokter FK UNUD sudah cukup sering menjadi subjek dari berbagai penelitian baik yang dilakukan oleh mahasiswa program studi pendidikan dokter sendiri atau dari program studi lain. Keterbatasan yang dimiliki peneliti selanjutnya adalah sulitnya melakukan kategorisasi pekerjaan orangtua dan domisili subjek karena terdapat berbagai variasi dalam pekerjaan orangtua dan domisili yang ditulis dalam kuisioner. Kesulitan dalam kategorisasi menyebabkan peneliti tidak bisa melakukan analisis karakteristik subjek penelitian.

Setelah melakukan prosedur analisis data penelitian, karya tulis ini telah mencapai tujuan penelitian yaitu mengetahui peran pola asuh autoritatif dan kecerdasan emosional terhadap problem focused coping pada remaja akhir di Program Studi Pendidikan Dokter FK UNUD, mengetahui peran pola asuh autoritatif terhadap problem focused coping remaja akhir di Program Studi Pendidikan Dokter FK UNUD, dan mengetahui peran kecerdasan emosional terhadap problem focused coping remaja akhir di Program Studi Pendidikan Dokter FK UNUD.

Berdasarkan penelitian yang telah dilakukan dapat ditarik kesimpulan bahwa pola asuh autoritatif dan kecerdasan emosional secara bersama-sama berpengaruh terhadap problem focused coping pada remaja akhir di Program Studi Pendidikan Dokter FK UNUD, kecerdasan emosional memiliki peran yang signifikan terhadap problem focused copingi pada remaja akhir di Program Studi Pendidikan Dokter FK UNUD, secara parsial pola asuh autoritatif tidak memiliki peran yang signifikan terhadap problem focused coping pada remaja akhir di Program Studi Pendidikan Dokter FK UNUD, problem focused coping pada remaja akhir di Program Studi Pendidikan Dokter FK UNUD mayoritas tinggi dengan persentase sebesar 69,2\%, kecerdasan emosional pada remaja akhir di Program Studi Pendidikan Dokter FK UNUD mayoritas tinggi dengan persentase sebesar $68,6 \%$, pola asuh autoritatif yang diterapkan oleh orangtua remaja akhir di Program Studi Pendidikan Dokter FK UNUD mayoritas tinggi dengan persentase sebesar $91 \%$.

Berdasarkan kesimpulan yang telah dipaparkan, maka peneliti dapat memberikan saran untuk remaja akhir yaitu remaja akhir di Program Studi Pendidikan Dokter FK diharapkan dapat melakukan kegiatan berdiskusi di luar proses perkuliahan, seperti berdiskusi dengan orangtua, keluarga dan teman, serta belajar berkelompok maupun kegiatan organisasi yang dilakukan bersama teman, karena dapat mengembangkan potensi diri lebih banyak sehingga meningkatkan kecerdasan emosional dan usaha menghadapi masalah lebih efektif.
Remaja akhir di Program Studi Pendidikan Dokter FK juga diharapkan dapat mempertahankan kecerdasan emosional yang tinggi sehingga dapat memiliki kemampuan mengelola diri dan membina hubungan yang baik dengan orang lain sehingga dapat menggunakan potensi yang dimiliki secara maksimal dalam menghadapi berbagai situasi maupun dalam menghadapi masalah.

Saran untuk orangtua yaitu orangtua remaja akhir Program Studi Pendidikan Dokter FK UNUD dapat mempertahankan pola asuh autoritatif guna meningkatkan pengembangkan kecerdasan emosional remaja akhir, karena pada penelitian ini secara parsial peran pola asuh autoritatif tidak secara langsung berperan terhadap problem focused coping pada remaja akhir, namun pola asuh autoritatif berperan secara langsung terhadap kecerdasan emosional remaja akhir sehingga orangtua autoritatif dapat membuat suatu rutinitas untuk mengembangkan 25 kecakapan emosi pada anak. Salah satu rutinitas yang dapat dilakukan orangtua yaitu setiap pagi sebelum berangkat ke sekolah, setiap siang setelah pulang sekolah dan setiap malam sebelum tidur, anak diminta untuk menulis bagaimana perasaan yang dirasakan disebuah papan. Rutinitas tersebut menyebabkan anak mampu mengenali emosi yang dirasakan dan membuat orangtua dapat memperhatikan perubahan emosi yang dirasakan anak. Ketika orangtua dapat melihat perubahan emosi anak, orangtua dapat melakukan pendekatan dengan anak untuk melakukan diskusi untuk mengetahui bagaimana cara mengelola emosi dan bagaimana dampak dari emosi yang dirasakan. Maka, anak dapat meningkatkan kecerdasan emosional yang kemudian akan mempengaruhi anak dalam menghadapi masalah secara efektif.

Saran untuk organisasi mahasiswa yaitu organisasi mahasiswa sebagai salah satu pihak universitas dapat membuat kegiatan diskusi diluar proses perkuliahan seperti membuka forum diskusi mengenai peristiwa-peristiwa yang menjadi sorotan pengembangan pengetahuan yang ditekuni sehingga kecerdasan emosional semakin meningkat karena wawasan mahasiswa semakin luas dan menyebabkan mahasiswa mampu membina hubungan yang baik dengan orang lain. Meningkatnya kecerdasan emosional dapat mempengaruhi mahasiswa dalam menghadapi masalah secara efektif.

Saran untuk peneliti selanjutnya yaitu peneliti selanjutnya dapat melakukan penelitian dengan menggunakan subjek yang berasal dari program studi lain atau fakultas lain untuk melihat problem focused coping atau koping yang berfokus pada permasalahan sehingga dapat menghindari terjadinya data penelitian berdistribusi tidak normal. Pada penelitian ini belum ada analisis beda dari kategorisasi identitas subjek karena sulitnya melakukan kategorisasi pada pekerjaan dan domisili subjek. Maka, peneliti selanjutnya diharapkan dapat menentukan secara langsung kategorisasi 
identitas subjek agar mempermudah peneliti dalam melakukan kategorisasi dan mendapatkan referensi penelitian yang berkaitan dengan kategori tersebut serta dapat mencari hubungan dari pekerjaan orangtua dan domisili terhadap pola asuh autoritatif, kecerdasan emosional atau problem focused coping. Peneliti selanjutnya dapat melakukan penelitian dengan menggunakan subjek dengan karakteristik remaja awal, remaja akhir dan dewasa untuk melihat problem focused coping, kecerdasan emosional dan pola asuh autoritatif yang diterapkan oleh orangtua pada masing-masing periode perkembangan manusia. Peneliti selanjutnya dapat melakukan penelitian dengan menggunakan variabel bebas pola asuh autoritatif dan variabel intervening kecerdasan emosional untuk mengukur taraf problem focused coping. Peneliti selanjutnya dapat merancang suatu program atau penelitian eksperimen untuk meneliti lebih lanjut efektivitas proses diskusi atau SGD dalam mengembangkan problem focused coping dan kecerdasan emosional individu.

\section{DAFTAR PUSTAKA}

Abdulghani, H. M., Alkanhal, A. A., Mahmoud, E. S., Ponnaperuma, G. G., \& Alfaris, E. A. (2011). Stress and Its Effects On Medical Students: A Cross-sectional Study at a College of Medicine in Saudi Arabia. Journal of Health, Population, and Nutrition, 29(5), 516-522.

Ali, M. \& Asrori, M. (2012). Psikologi Remaja: Perkembangan Peserta Didik. Jakarta: PT Bumi Aksara.

Baumrind, D. (1966). Effects of Autoritative Parental Control on Child Behavior. Child Development, 37(4), 887-907.

Baumrind, D. (1971). Current Patterns of Parental Authority. Developmental Psychology, 4(1, Pt.2),1-103.

Baumrind, D. (1991). The Influence of Parenting Style on Adolescent Competence and Substance Use. The Journal of Early Adolescence, 11, 56-95. doi:10.1177/0272431691111004.

Carver, C. S., Scheier, M., \& Weintraub, J. K. (1989). Assessing Coping Strategies: A Theoretically Based Approach. Journal of Personality and Soial Psyhology, 56(2), 267-283.

Darling, N \& Steinberg, L. (1993). Parenting Style as Context: An Integrative Model. Psychological Bulletin, 113(3), 487-496.

Dasmo, Nurhayati \& Marhento, G. (2012). Pengaruh Tingkat Pendidikan dan Pola Asuh Orangtua Terhadap Prestasi Belajar IPA. ISSN: 2088-351X, 132-139.

Fadillah, R. (2013, 31 Mei). Dua Remaja Cewek Di Bogor Pesta Narkoba Untuk Senang-Senang. Diambil dari Merdeka.com: http://www.merdeka.com/jakarta/duaremaja-cewek-di-bogor-pesta-narkoba-untuk-senangsenang.html. Diakses pada 22-12-2015

Fajarwati, D. H.S. (2005). Hubungan Antara Kecerdasan Emosional Dengan Problem Focused Coping Pada Remaja. Skripsi (Tidak Diterbitkan). Fakultas Psikolgi Universitas Ahmad Dahlan, Yogyakarta.

Farida, L. N. \& Naviati, E. (2014). Hubungan Pola Asuh Otoritatif Dengan Perkembangan Mental Emosional Pada Anak Usia Prasekolah Di TK Melati Putih Banyumanik. Prosiding Seminar Nasional, 2(2), 222-228.
Folkman, S., Lazarus, R. S., Dunkel-Schetter, C., DeLongis, A., \& Gruen R. J. (1986). Dynamics of a Stressful Encounter: Cognitive Appraisal, Coping, and Encounter Outcomes. Journal of Personality and Social Psychology, 50(5), 9921003.

Goleman, D. (2000). Kecerdasan Emosi untuk Mencapai Puncak Prestasi. Jakarta: PT. Gramedia Pustaka Utama.

Goleman, D. (2015). Kecerdasan Emosional. Jakarta : PT. Gramedia Pustaka Utama.

Haryanti, D. (2014). Hubungan Pola Asuh Orang Tua Dengan Harga Diri Siswa Di SMAN 1 Kretek Bantul. Skripsi (Tidak Diterbitkan). Program Studi Ilmu Keperawatan Sekolah Tinggi Ilmu Kesehatan 'Aisyiyah, Yogyakarta.

Hurlock, E. B. (1980). Psikologi Perkembangan Suatu Pendekatan Sepanjang Rentang Kehidupan (5th ed.). Jakarta: Erlangga.

Maulana, Z. F., Soleha, T.U., Saftarina, F., \& Siagian J. M. C. (2014). Perbedaan Tingkat Stres Antara Mahasiswa Tahun Pertama dan Tahun Kedua di Fakultas Kedokteran Universitas Lampung. ISSN 2337,3776, 154-162.

Navas, P. S. (2012). Stress Among Medical Students. Kerala Medical Journal, 2(2), 5-7.

Lazarus, R. S. (1993). From Psychological Stress To The Emotions: A History of Changing Outlooks. Annu. Rev. Psychol., 44, $1-21$.

Papalia, D.E., Olds, S.W. \& Feldman, R.D. (2009). Human Development Perkembangan Manusia (10th ed.). Jakarta: Salemba Humanika.

Priyatno, D. (2012). Belajar Praktis Analisis Parametrik Dan Non Parametrik Dengan SPSS. Yogyakarta: Gava Media.

Respati, W.S., Yulianto, A., Widiana, N. (2006). Perbedaan Konsep Diri Antara Remaja Akhir Yang Mempersepsi Pola Asuh Orangtua Authoritarian, Permissive Dan Authoritative. Jurnal Psikologi, 4(2), 119-138.

Rohmah, F. A. (2006). Pengaruh Diskusi Kelompok Untuk Menurunkan Stres Pada Mahasiswa Yang Sedang Skripsi. Humanitas, 3(1), 50-62.

Rustika, I. M. (2014). Faktor-Faktor yang Mempengaruhi Prestasi Akademik pada Remaja. Disertasi (tidak diterbitkan). Fakultas Psikologi Universitas Gadjah Mada, Yogyakarta.

Safaria, T. (2006). Stress Ditinjau Dari Active Coping, Avoidance Coping dan Negative Coping. Humanitas, 3(2), 87-93.

Santoso, S. (2003). Mengatasi Berbagai Masalah Statistika dengan SPSS versi 11.5. Jakarta: PT Elex Media Komputindo.

Santrock, J. W. (2007a). Remaja (11th ed., Vol. 1). Jakarta: Erlangga. Santrock, J. W. (2007b). Remaja (11th ed., Vol. 2). Jakarta: Erlangga. Saptoto, R. (2010). Hubungan Kecerdasan Emosi dengan Kemampuan Coping Adaptif. Jurnal Psikologi, 37(1), 1322.

Sari, P. (2010). Coping Stress Pada Remaja Korban Bullying Di Sekolah "X". Jurnal Psikologi, 8(2), 75-81.

Sarwono, S. W. (2013). Psikologi Remaja. Jakarta: Rajawali Pers.

Seiffge-Krenke, I., Aunola, K., \& Nurmi, J. (2009). Changes in Stress Perception and Coping During Adolescence: The Role of Situational and Personal Factors. Journal Compilation, 80(1), 259-279.

Sugiyono. (2012). Statistika untuk Penelitian. Bandung: Alfabeta. 
Suparmi \& Ngahu, I. K. (2006). Problem Solving Skills Pada Remaja Ditinjau Dari Pola Asuh Autoritatif Orangtua Dan Intelegensi. Psikodimensia, 5(2),139-150.

Suryani \& Hendryadi. (2015). Metode Riset Kuantitatif Teori dan Aplikasi Pada Penelitian Bidang Manajemen dan Ekonomi Islam. Jakarta: Prenadamedia Group.

Suryanis, A. (2014, 20 Agustus). BNN: 22 Persen Pelajar dan Mahasiswa Pakai Narkoba. Diambil dari Metro: http://metro.tempo.co/read/news/2014/08/20/064601070/bn n-22-persen-pelajar-dan-mahasiswa-pakai-narkoba. Diakses pada 21-12-2015

Surve, R., Dase, R., Pawar, K., Jadhav, V., Shah, A., Shrivastava, N., Shah, R., \& T, Z. (2015). Assessment of Stress Level Among Medical Student of MGM Medical College and Hospital Aurangabad [MS]. International Journal of Current Medical and Applied Sciences, 5(3), 156-160.

Susanto, D. M. (2013). Keterlibatan Ayah Dalam Pengasuhan, Kemampuan Coping dan Resiliensi Remaja. Jurnal Sains dan Praktik Psikologi, 1(2), 101-113.

Tribun Batam. (2015, 20 Desember). Saat Asyik Pesta Miras, Polresta Barelang Bekuk 24 Anggota Geng Motor. Diambil dari Tribun News: http://www.batam.tribunnews.com/2015/12/20/saat-asyikpesta-miras-polresta-barelang-bekuk-24-anggota-gengmotor. Diakses pada 22-12-2015.

Wolfaardt, U., Hempel, S., \& Miles, J. N. V. (2003). Perceived Parenting Styles, Depersonalisation, Anxiety And Coping Behaviour In Adolescents. Personality and Individual Differences, 34, 521-532. 